\title{
Change in parameters and injection times of a divided fuel dose
}

\begin{abstract}
This paper presents test results of the effect of preset interval time on calculated times and parameters of fuel injection. The measurements comprised tests on the test stand with the use of an electronically controlled injection dose indicator. Division of the dose into two parts was accomplished. The fuel pressure in the rail was maintained at a constant level. A substantial change in the injection parameters was shown, such as the flow rate of fuel from the nozzle, and particularly, calculated injection times, which are always greater than the total, preset ones. For a given pressure in the rail there exists a certain limit value of the interval, for which division of the dose into parts is accomplished. The introduction of gravity centres of injection runs is proposed to evaluate the process of fuel dosage.
\end{abstract}

Keywords: diesel engine, common rail, divided dose, injection time

\section{Zmiany parametrów i czasu wtrysku dzielonej dawki paliwa}

W pracy przedstawiono wyniki badań wptywu zadanego czasu przerwy na obliczone czasy i parametry wtrysku paliwa. Pomiary obejmowaty badania stanowiskowe na stole probierczym, z wykorzystaniem elektronicznie sterowanego indykatora dawki wtrysku. Zadawano podziat dawki na dwie części. Ciśnienie paliwa w zasobniku utrzymywano na stałym poziomie. Wykazano, że w istotny sposób zmieniaja się parametry wtrysku, takie jak natężenie wyptywu paliwa z rozpylacza, a zwłaszcza obliczone czasy wtrysku, które sa zawsze większe od całkowitych, zadanych. Dla danej wartości ciśnienia w zasobniku istnieje pewna wartość graniczna czasu przerwy, dla której jest realizowany podziat dawki na części. Zaproponowano wprowadzenie środków ciężkości przebiegów wtrysku do oceny procesu dawkowania paliwa.

Słowa kluczowe: silnik o zapłonie samoczynnym, common rail, dzielona dawka, czas wtrysku

\section{Introduction}

Ongoing efforts striving towards the construction of more perfect reciprocating automotive combustion engines result from the necessity of compliance with requirements of high efficiency, reliability, and more and more stringent regulations concerning the emission of pollutants. The last point, connected mainly with the combustion of hydrocarbon fuels, also applies to emission of carbon dioxide, directly connected with the consumption of operating fuel. In such a situation, perfection of the combustion process belongs to one from the most important directions of engine development. It involves the natural pursuit of development of more efficient and better controlled fuel supply systems. Usage of suitable control algorithms and selection of suitable injection times enable both the required parameters of engine operation to be obtained, and fulfillment of regulatory requirements concerning the cleanliness of exhaust gases.

Self-ignited combustion engines manufactured today are equipped with high pressure accumulator systems of common rail type by a large majority. The main advantages of such systems include the possibility of control of engine operation over a broad range of the operation, i.e. controlling time and pressure, as well as the form of the injection. Knowledge of the injection time is important, because during operation of the injection system, based on the value of this time, changes occur in the quantity of the fuel supplied to the combustion engine's cylinder.

Analyses of injection processes in fuel supply systems with common rail systems have shown differences between

\section{Wprowadzenie}

Ciągłe dążenie do konstruowania coraz doskonalszych tłokowych, samochodowych silników spalinowych jest spowodowane koniecznością zapewnienia ich wysokiej sprawności, niezawodności oraz spełnieniem przez nie coraz bardziej rygorystycznych przepisów dotyczących emisji zanieczyszczeń. To ostatnie, związane ze spalaniem zwłaszcza paliw węglowodorowych, odnosi się także do emisji dwutlenku węgla, wielkości związanej bezpośrednio z eksploatacyjnym zużyciem paliwa. W tej sytuacji jednym z najważniejszych kierunków rozwoju silników jest doskonalenie procesu spalania. Wywołuje to naturalne dążenie do opracowania coraz wydajniejszych i coraz lepiej sterowanych systemów zasilania w paliwo. Zastosowanie właściwych algorytmów sterowania oraz dobór odpowiednich czasów wtrysku, umożliwiają osiągnięcie zarówno żądanych parametrów pracy silnika, jak i spełnienie określonych prawem norm czystości spalin.

Współcześnie produkowane silniki spalinowe o zapłonie samoczynnym w zdecydowanej większości są wyposażane w wysokociśnieniowe zasobnikowe układy zasilania w paliwo (common rail). Główną zaletą tych systemów jest możliwość sterowania w szerokim zakresie pracy silnika zarówno czasem i ciśnieniem, jak i formą wtrysku. Znajomość czasu wtrysku jest ważna, ponieważ podczas pracy układu wtryskowego w oparciu o wartości tej wielkości następuje zmiana ilości paliwa doprowadzanego do cylindra silnika spalinowego.

Analizy procesów wtrysku realizowanych przez zasobnikowe układy zasilania wykazały różnice, między czasami 
the time of injection as preset by controller, and the time of injection accomplished in reality by the injection system. In the work presented in this paper, an attempt was undertaken to assess the change of the time and injection parameters of a divided fuel dose, as a function of preset times of the interval at fixed pressure in the common rail.

The present paper is the third publication dealing with analysis of multipart dose injection of fuel. In the first paper [1], characteristic injection times as a function of parameters of the injection system's operation are presented injection times, while in the second publication controlled injection times and times of lift of the nozzle's needle are discussed injection times [2].

\section{Scope of the analysis}

At steady pressure values in the common rail, injection times determine the quantity of injected fuel and the form of the injection.

Values of the time input to the read-only memory of the control module of the engine, or to the operational memory of the research controller are called injection times. In considerations of this topic the term "calculated times" has also been introduced. The calculated times should be understood as times of injection of individual parts of the dose and times of the interval between injections, determined on the base of pressure increments in the injection dose indicator and calculated injection runs. To do this, it is necessary to make use of dependencies resulting from an equation of conservation of mass, to carry out an approximation of the measured runs, and to consider changes of the parameters of the injected fuel. Hence, these are not directly obtained times, for instance during measurements of lift of the needle; these are obtained indirectly, on the base of recalculations, taking into consideration additional values. In such a way injection runs are determined, while the injection time and characteristic parameters of the flow of fuel from the injector directly result from the run. Calculated injection times constitute the response of the system to the preset times.

Based on the above, it is possible to determine relations between preset, electric control runs of the injectors in the fuel supply system and calculated injection times, which reflect changes in the fuel stream supplied to a cylinder of the engine. They are useful during optimization of the combustion process in cases where different forms of injection are used, and hence in a situation of fuel supply with divided injection doses.

The substantial role of the interval time has already been confirmed during earlier investigations accomplished with participation of the authors, performed on test stands and engine dynos [6]. In the case of multiphase injection, a distinct dependency of the size of supplied fuel dose on the interval time was recorded. The total dose of supplied fuel changed together with growth of the interval between the parts of the dose. It is an important issue, because it inhibits the possibilities of correctly shaping the operational parameters of the engine. Moreover, an uncontrolled change in the quantity of supplied liquid fuel can significantly change the efficiency of the engine. In diagrams of fuel dosage a narrow wtrysku zadawanymi za pomocą sterownika, a czasami wtrysku rzeczywiście realizowanymi przez układ wtryskowy. W pracy podjęto próbę oceny zmian czasów i parametrów wtrysku dzielonej dawki paliwa, w zależności od zadanych czasów przerwy, przy ustalonym ciśnieniu w zasobniku.

Niniejszy artykuł jest trzecią publikacją poświęconą analizie wtrysku wieloczęściowej dawki paliwa. W pierwszej [1] przedstawiono charakterystyczne czasy wtrysku w zależności od parametrów pracy układu wtryskowego, a w drugiej omówiono sterowane czasy wtrysku i czasy uniesienia iglicy [2].

\section{Zakres analizy}

Przy ustalonych wartościach ciśnienia w zasobniku, czasy wtrysku decydują o ilości wtryskiwanego paliwa oraz o formie wtrysku.

Te, które są wprowadzane do pamięci stałej modułu sterującego silnika lub operacyjnej do badawczego sterownika nazwano zadanymi czasami wtrysku. Do rozważań wprowadzono również pojęcie „obliczone czasy”. Pod tym pojęciem rozumie się czasy wtrysku poszczególnych części dawki i czasy przerw między nimi, wyznaczone w oparciu o przyrosty ciśnienia w indykatorze dawki wtrysku i obliczone przebiegi wtrysku. Konieczne jest przy tym wykorzystanie zależności wynikających z równania zachowania masy, przeprowadzenie aproksymacji zmierzonych przebiegów oraz uwzględnienia zmian parametrów wtryskiwanego paliwa. Nie są to zatem czasy uzyskane w sposób bezpośredni, na przykład przez pomiar wzniosu iglicy, a w sposób pośredni, w oparciu o przeliczenia z uwzględnieniem dodatkowych wielkości. W ten sposób zostają wyznaczone przebiegi wtrysku, a z nich wprost wynikają czasy wtrysku i charakterystyczne parametry wypływu paliwa z wtryskiwacza. Obliczone czasy wtrysku są odpowiedzią układu na zadane czasy.

W oparciu o powyższe jest możliwe określenie relacji między zadanymi, elektrycznymi przebiegami sterującymi wtryskiwaczami układu zasilania, a obliczonymi czasami wtrysku, które odzwierciedlają zmiany strumienia paliwa podawanego do cylindra silnika. Są one przydatne przy optymalizacji procesu spalania w przypadkach stosowania różnych form wtrysku, a więc tam gdzie są podawane dzielone dawki wtrysku.

Istotną rolę czasu przerwy stwierdzono już podczas wcześniejszych badań będących udziałem autorów, a prowadzonych na silnikowych i bezsilnikowych stanowiskach [6]. Przy stosowaniu wielofazowego wtrysku, odnotowano wyraźną zależność wielkości podawanej dawki paliwa od czasu przerwy. W miarę wzrostu czasu przerwy między częściami dawki, zmieniała się całkowita podawana dawka paliwa. Jest to ważne zagadnienie, bowiem utrudnia możliwości właściwego kształtowania parametrów pracy silnika. Ponadto niekontrolowana zmiana ilości podawanego ciekłego paliwa może w istotny sposób zmienić sprawność silnika. Na wykresach dawkowania daje się zauważyć wąski przedział (około $40 \mu \mathrm{s}$ ) wartości czasu przerwy w którym, po wzroście, następuje zmniejszanie sumarycznego dawkowania. Jest to wielkość charakterystyczna dla każdego typu wtryskiwacza i nazwano ją „czasem reakcji”. 
range (of about $40 \mu \mathrm{s}$ ) of the interval time value can be seen, in which after an increase in the time a reduction of the total dosage occurs. This is a characteristic feature of any type of injector, and is known as the "time of reaction".

Due to the above, and with reference to earlier measurements, investigations of the effect of the preset interval time on calculated times and parameters of fuel injection were performed. The measurements consisted of stand tests on a test bench, using an electronically controlled fuel dose indicator $[3,5]$. Calculated injection times were determined on the basis of voltage runs in a piezo quartz pressure pick-up of type GU-21D made by the firm AVL, incorporated into the indicator's chamber. The runs were measured at the inlet to the device, with the use of a Tektronix TDS-3014 digital oscilloscope. The runs constituted the basis for determining calculated injection times and characteristic values connected with the injection run of a divided dose.

Analyses were performed for a series of measurements with preset division of the dose into two parts. In all cases, constant values of preset time of opening of the injector (the first part $262 \mu \mathrm{s}$, the second part $464 \mu \mathrm{s}$ ) were assumed, while one measured preset times of the interval - from $200 \mu$ s to $377 \mu$ s. The last value concerns the case when distinct division of the dose into two parts was obtained. The pressure of the fuel in the rail was maintained at the level of $70 \mathrm{MPa}$.

\section{Analysis of parameters and injection times}

In Figure 1, depending on the preset interval time, compiled runs of injection calculated for measured cases of the measurement are shown, with times of the duration of the injection marked. In Table 1 their synthetic descriptions are listed, comprising the times of the interval, the calculated injection time, the fuel dose, the form of the injection, and the maximum value of the fuel flow rate from the nozzle, as well as the time taken to reach this maximum value. In turn, in Fig. 2 all the curves of the fuel flow rate from the nozzle are collated, starting from the first (undivided), to the final

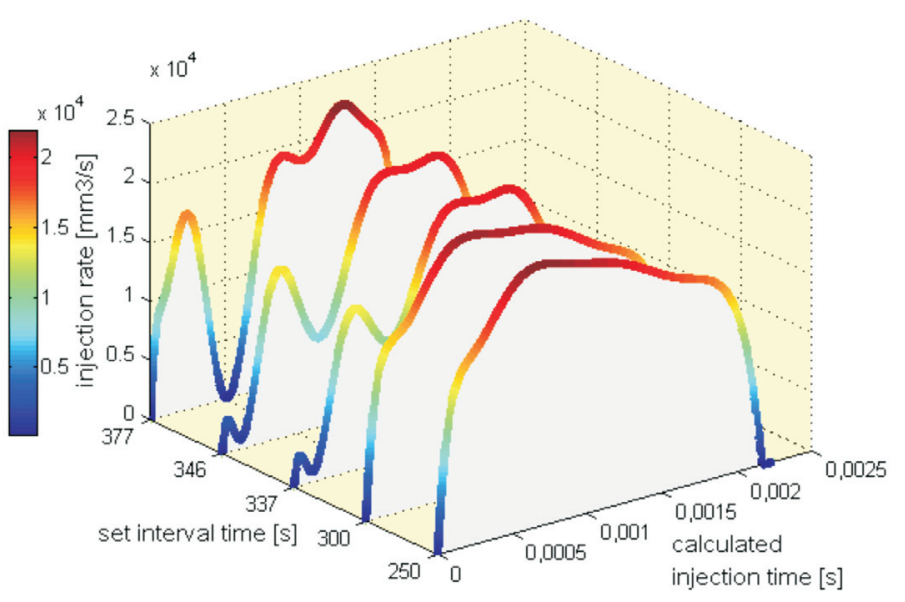

Fig. 1. Injection rates of a two-part dose as a function of the preset interval time Rys. 1. Przebiegi wtrysku dwuczęściowej dawki w zależności od zadanego czasu przerwy
W związku z powyższym i w nawiązaniu do wcześniejszych pomiarów, przeprowadzono badania wpływu zadanego czasu przerwy na obliczone czasy i parametry wtrysku paliwa. Pomiary obejmowały badania stanowiskowe na stole probierczym, z wykorzystaniem elektronicznie sterowanego indykatora dawki wtrysku $[3,5]$. Obliczane czasy wtrysku wyznaczano w oparciu o przebiegi zmian napięcia piezokwarcowego czujnika ciśnienia GU-21D firmy AVL, umieszczonego w komorze indykatora. Przebiegi mierzono na wyjściu z urządzenia, za pomocą oscyloskopu cyfrowego Tektronix TDS-3014. Stanowiły one podstawę do wyznaczenia obliczonych czasów wtrysku oraz charakterystycznych wielkości związanych z przebiegiem wtrysku dzielonej dawki.

Rozważania przeprowadzono dla serii pomiarów, podczas której zadawano podział dawki na dwie części. We wszystkich przypadkach przyjęto stałe wartości zadawanych czasów otwarcia wtryskiwacza (pierwsza część $262 \mu \mathrm{s}$, druga $464 \mu \mathrm{s}$ ), natomiast zmieniano zadawane czasy przerw - od $200 \mu$ s do $377 \mu$ s. Ta ostatnia wartość dotyczy przypadku, dla którego uzyskano wyraźny podział dawki na dwie części. Ciśnienie paliwa w zasobniku utrzymywano na poziomie $70 \mathrm{MPa}$.

\section{Analiza parametrów i czasów wtrysku}

Na rysunku 1, w zależności od zadanego czasu przerwy, zestawiono przebiegi wtrysku obliczone dla zmierzonych przypadków pomiarowych, z zaznaczonymi czasami trwania wtrysku. W tablicy 1 przygotowano ich syntetyczne opisy, obejmujące czas przerwy, obliczony czas wtrysku, dawkę paliwa, formę wtrysku oraz maksymalną wartość natężenia wypływu paliwa $\mathrm{z}$ rozpylacza i czas po którym została osiągnięta. Z kolei na rys. 2 zestawiono wszystkie krzywe natężenia wypływu paliwa z rozpylacza, od pierwszej, jednoczęściowej, do ostatecznej, już z podziałem na części.

Z przedstawionych przebiegów natężenia wypływu paliwa z rozpylacza wynika, że zadane czasy przerwy między kolejnymi częściami dawki mniejsze od $300 \mu$ s nie zmieniają charakteru wtrysku, lecz nieznacznie zwiększają czas trwania wtrysku. W ten sposób, przy praktycznie niezmiennym (zwłaszcza w obszarze maksymalnych wartości) natężeniu wypływu paliwa z rozpylacza, zmniejsza się ilość podawanego paliwa. Należy wyraźnie podkreślić, że niniejsze rozważania dotyczą wartości czasów przerwy większych od czasu reakcji wtryskiwacza, a więc obszaru, w którym następuje zmniejszanie dawkowania. Istotne zmiany przebiegu wtrysku są widoczne dopiero dla czasów przerwy większych od $337 \mu$ s. Tu, przy dalszym zmniejszaniu czasu wtrysku następuje zmniejszanie maksymalnych wartości oraz wyraźna zmiana charakteru przebiegu. Występuje lokalne minimum, które jest odzwierciedleniem zadanego czasu przerwy i pogłębia się z jego wzrostem. Ta forma podawania paliwa znakomicie ilustruje przewagę zasobnikowego układu zasilania nad innymi, wcześniej stosowanymi. Możliwość zmiany strumienia dopro- 
Table 1. Injection rates for constant rail pressure and variable preset interval time Tab. 1. Przebiegi wtrysku dla stałej wartości ciśnienia paliwa w zasobniku i zmiennych wartości czasu przerwy

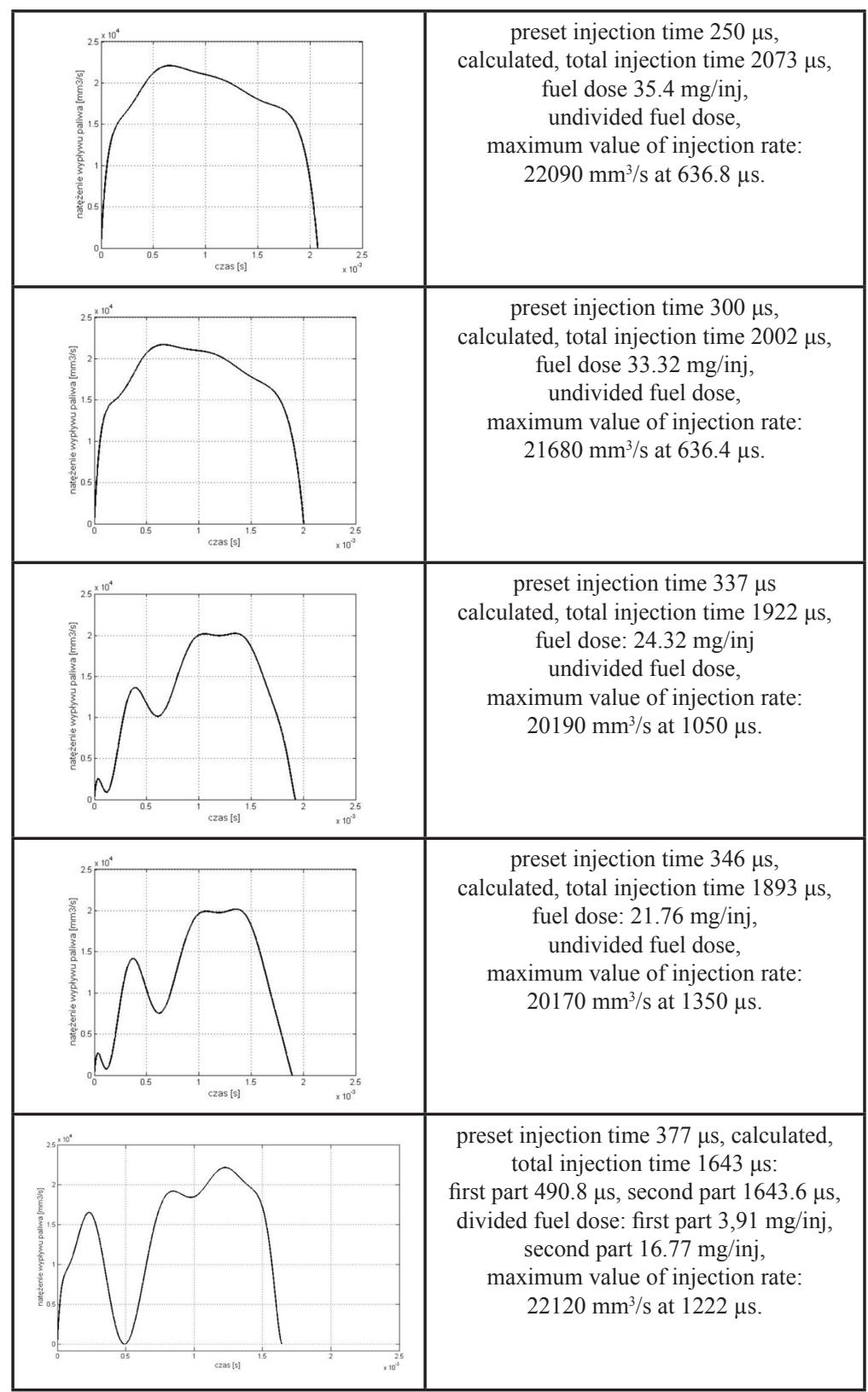

one, with a division into parts.

From the runs of fuel flow rate presented, it can be seen that the preset times of the interval between successive parts of the dose, where smaller than $300 \mu$ s, do not change the character of the injection, but slightly increase the time of duration injection time. In such a way, at a practically constant value of the fuel's flow rate from the nozzle (especially in area of maximum values), the quantity of fuel supplied decreases. It should be clearly emphasized that the present considerations concern values of the interval times greater than the reaction time of the injector, and hence the area in which the reduction of dosage occurs. Important changes in the injection run are visible only from times of the interval greater than $337 \mu \mathrm{s}$ onwards. Here, reductions in the maximum values and clear wadzanego paliwa w czasie procesu wtrysku, znacząco zwiększa możliwości kształtowania procesu wydzielania ciepła w cylindrze silnika. Można zatem bardzo dokładnie i w szerokim zakresie wpływać na wskaźniki i parametry pracy silnika.

Przy dalszym wzroście czasu przerwy sumaryczna dawka cały czas maleje. Dopiero po przekroczeniu wartości czasu przerwy równej $377 \mu$ s, zostaje zrealizowany podział dawki paliwa na części, to znaczy po podaniu pierwszej części ma miejsce zamknięcie iglicy wtryskiwacza, a po krótkiej przerwie ponowne jej uniesienie. Zwiększony udział czasu przerwy w całkowitym czasie wtrysku, powoduje znaczące zmniejszenie czasu wtrysku i jednoczesne ponowne zwiększenie maksymalnych wartości natężenia przepływu do poziomu uzyskiwanego dla najmniejszych wartości przerw. Te zmiany dobrze ilustruje rys. 3, gdzie przedstawiono je właśnie w zależności od czasu przerwy.

Próbę wyznaczenia i oceny kierunków zmian maksymalnych wartości przebiegu wtrysku przedstawiono na rys. 4 . Na tle wspomnianych już maksymalnych wartości (linia czerwonego koloru), wykreślono przebiegi czasu wystąpienia maksymalnych wartości (niebieska linia) oraz szybkości osiągania maksymalnych wartości (linia zielona). Przez czas wystąpienia maksymalnych wartości rozumie się wartość mierzoną od rozpoczęcia procesu wtrysku, do momentu osiągnięcia maksimum przebiegu. Te wartości rosną, a więc większe ilości energii będą dostarczane do silnika coraz później, w drugiej części procesu. Szybkości osiągania maksymalnych wartości wyznaczano jako iloraz tych wartości i czasu wystąpienia maksymalnych wartości. Tutaj następuje istotne zmniejszanie wartości, co również świadczy o rosnącym udziale drugiej części dawki. Zmiany omawianych wielkości wynikają z coraz większego udziału czasu przerwy w całkowitym czasie wtrysku.

Zmiany strumienia energii dostarczanej do cylindra silnika spalinowego, związane ze zmianami czasu przerwy, można dobrze zilustrować za pomocą powierzchni, przedstawiającej zmiany natężenia wypływu paliwa z rozpylacza, rozpiętej na wartościach czasu przerwy i obliczonego czasu wtrysku (rys. 5). Przy wykorzystaniu interpolacyjnej funkcji dwóch zmiennych, istnieje możliwość wyznaczenia przebiegów wtrysku dla innych, nie objętych pomiarami, wartości czasów przerw między częściami dawki, a więc również wyznaczyć prognozowaną dawkę wtrysku dla tych pośrednich wartości. Taki sposób postępowania może znacząco skrócić i uprościć proces przygotowania algorytmów sterujących silnikiem spalinowym o zapłonie samoczynnym. 
changes of character of the run occur, with a further reduction in the injection time. A distinct minimum reflecting preset interval time is present and the minimum deepens together with its growth. Such a form of fuel supply perfectly illustrates the advantage of the common rail fuel supply system over other systems, as used previously. The possibility of a change of stream of the supplied fuel during the course of the injection process considerably increases the possibilities of shaping the heat release process in the cylinder of the engine. It can be thereby possible to affect very accurately, and in a broad range, rates and parameters of engine operation.

With a further increase of the interval time, the total dose decreases all the time. Just after exceeding a value of the interval time of $377 \mu$ s, division of fuel dose into parts is accomplished, i.e. after supplying the first part, closure of injector's nozzle occurs, and after a short interval, a successive lift of the nozzle occurs. An increased share of the interval time in the total injection time event results in a considerable reduction of injection time and a simultaneous repeated increase in the maximum values of the flow rate, to the level obtained in the case of the smallest values of the intervals. Such changes are well illustrated in Fig. 3, where they are presented as a function of the interval time.

An attempt to determine and assess the directions of changes of the maximum values of the injection run is presented in Fig. 4. Against a background of the maximum values mentioned earlier (red line), runs of times of the occurrence of maximum values (blue line) and rates to achieve the maximum values (green line) are plotted. As the time of occurrence of the maximum values should be understood as a value measured from the commencement of the injection process to a moment when the maximum of the run has been achieved. These values grow, and hence bigger quantities of energy will be supplied to the engine later and later, in the second part of the process. The rate to achieve the maximum value was calculated as a quotient of these values and the time of occurrence of maximal values. Here, significant decrease of the values follow, which also testifies to the growing share of the second part of the dose. Changes in the values discussed result from the increasing share of the interval time in the total injection time event.

Changes in the energy stream supplied to the cylinder of a combustion engine, connected with changes of the interval time, can be well illustrated with the use of a surface plot, representing changes in the fuel flow rate from the nozzle, extended over values of the interval time and the calculated injection time (Fig. 5). Using an interpolation function with two variables, it is possible to determine injection runs for another part, not covered by the measurements, for values of the interval times between parts of the dose, and hence, also determine the predicted dose of the injection for these intermediate values. Such a way of proceeding can substantially shorten and simplify the process of preparation of algorithms used for control of a self-ignited combustion engine.

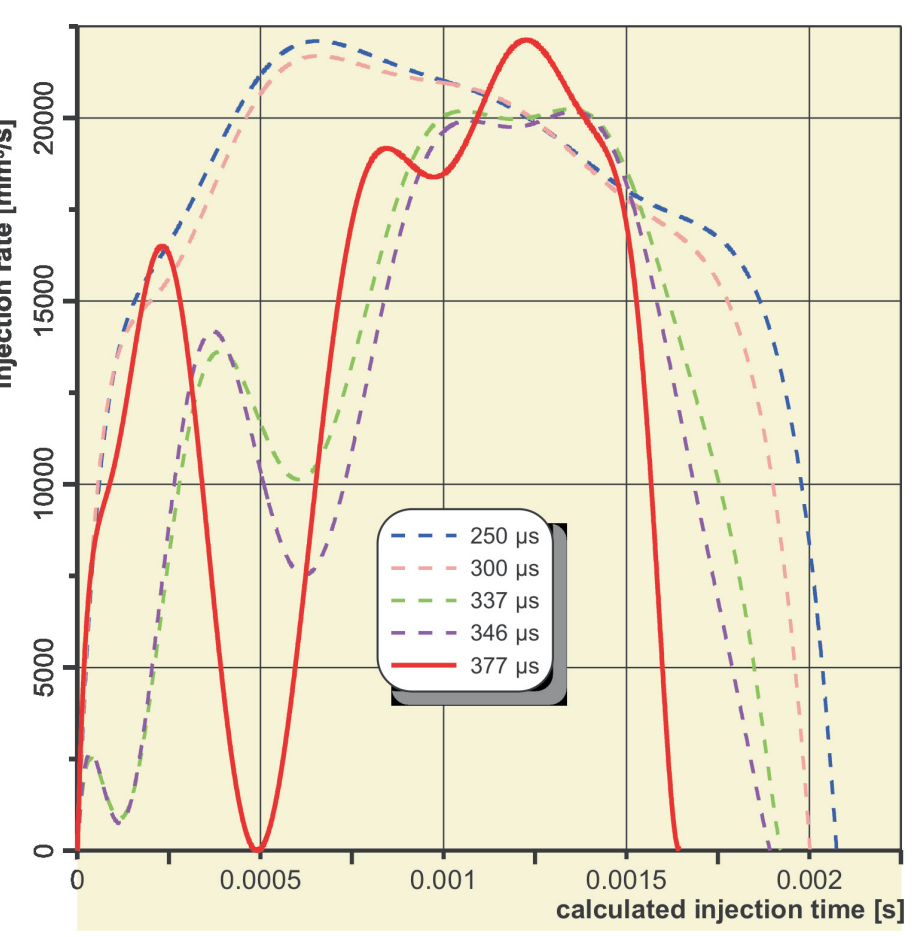

Fig. 2. Shapes of injection rate of two-part dose as a function of preset interval time

Rys. 2. Formy przebiegów wtrysku dwuczęściowej dawki w zależności od zadanego czasu przerwy

Inne ujęcie tego samego obszaru badawczego przedstawiono na rys. 6 . Jest to widok $z$ góry na powierzchnię utworzoną przez wartości: czas przerwy - obliczony czas wtrysku. Również i tu można w stanach pośrednich wyznaczyć czas wtrysku paliwa, ocenić formę wtrysku, czy przewidywać kierunek zmian natężenia wypływu paliwa z rozpylacza. Nie można jednak wyznaczyć przebiegów, a zatem i dawki wtrysku, co sprawia, że ta forma analizy wyników choć prostsza w przygotowaniu, ma ograniczone zastosowanie.

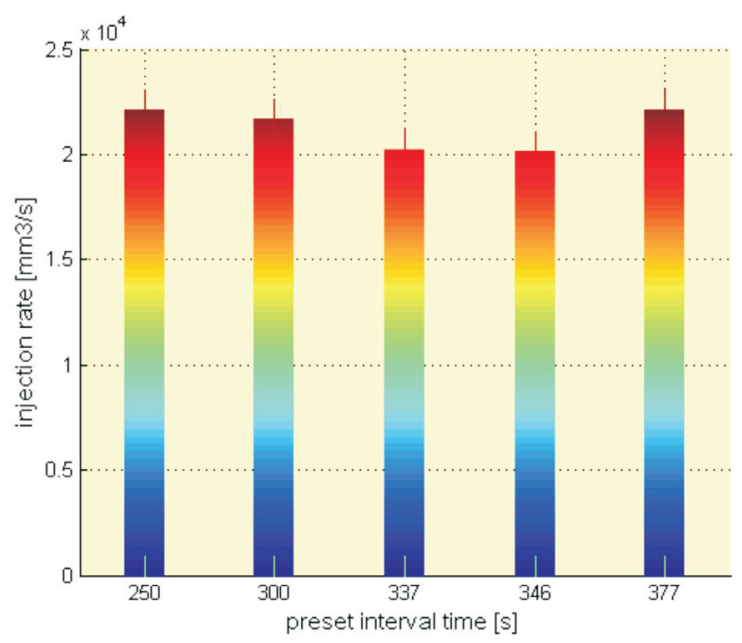

Fig. 3. Maximum value of injection rate as a function of preset injection time

Rys. 3. Zmiany maksymalnych wartości natężenia wyplywu paliwa z rozpylacza $w$ zależności od czasu przerwy 


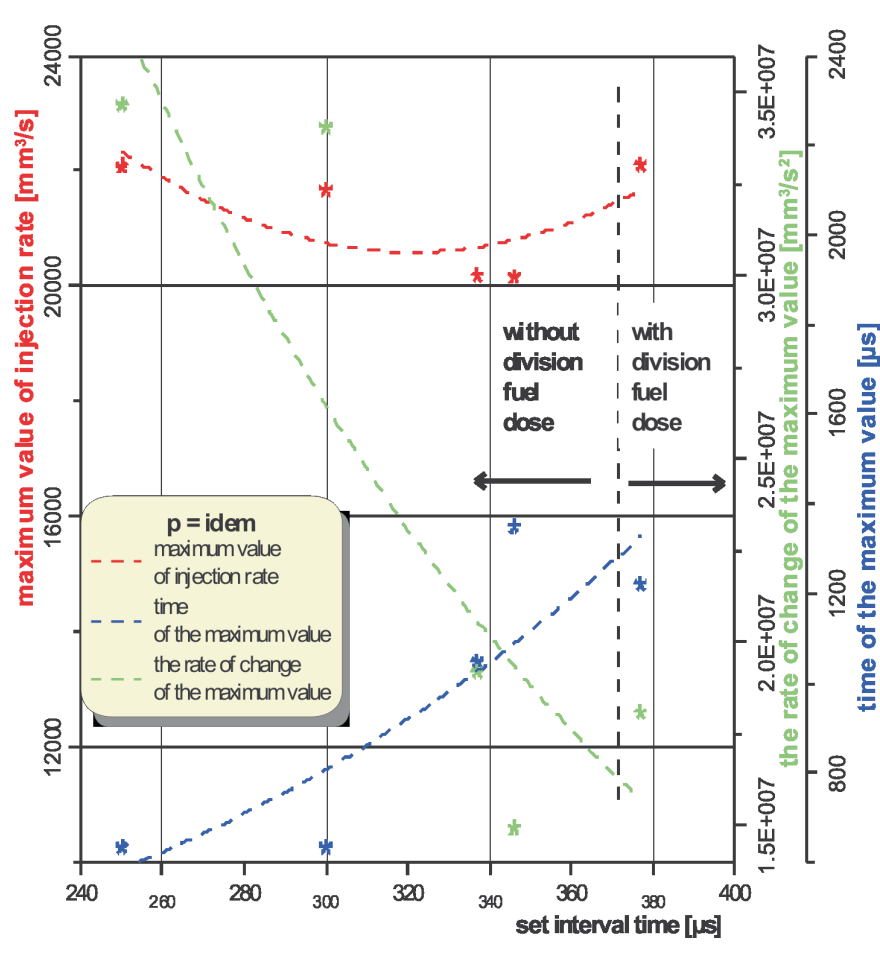

Fig. 4. Maximum value of injection rate, rate of change of the maximum value and time of the maximum value as a function of preset injection time Rys. 4. Przebiegi maksymalnych wartości, czasu ich wystapienia oraz szybkości zmian przebiegów wtrysku w zależności od czasu przerwy

Another approach for the same research area is presented in Fig. 6. It is the 'top' view of the surface created by the following values: interval time - calculated injection time. Here also it is possible to determine, in intermediate states, the time of fuel injection, to assess the form of the injection, or anticipate the direction of changes in the fuel flow rate from the nozzle. However, it is not possible to determine the runs, and hence the dose of the injection, meaning that such a form of analysis of the results - although more simple in terms of preparation - has limited applications.

Furthermore, an attempt at another type of synthetic assessment of changes in the energy stream supplied to the cylinder of a combustion engine was also undertaken, and accomplished through delivery of a two-part dose with a changing interval time. For this purpose a theory of probability was used, as known from other domains, and the method of assessment of the location of the center of gravity of the surface area of plain geometric figures. As is well known, the area (or areas in the case of a divided dose) under the curve of the injection run represents the total dose. Hence, a change of location of the center of gravity can be identified both with a change in the form, and with the distribution of quantities of fuel supplied in time. The centers of gravity were determined with use of the dependency known from theoretical mechanics and are presented in Fig. 7. According to Fig. 2, among the measurement cases analyzed, three forms of the injection can be distinguished: undivided, close to that accomplished by conventional systems; undivided, with modulated values of the fuel flow rate; and a two-part injection. It is obvious that each form of injection corresponds to a different location
Podjęto również próbę innego rodzaju syntetycznej oceny zmian strumienia energii dostarczanej do cylindra silnika spalinowego, a realizowanych przez zadawanie dwuczęściowej dawki, o zmiennym czasie przerwy. Do tego celu wykorzystano, znaną z innych dziedzin, np. rachunku prawdopodobieństwa, metodę oceny położenia środków ciężkości pól figur płaskich. Jak powszechnie wiadomo, pole (pola w przypadku dzielonej dawki) pod krzywą przebiegu wtrysku odzwierciedla sumaryczną dawkę. Zmianę położenia środka ciężkości można zatem utożsamiać zarówno ze zmianą formy, jak i rozłożeniem w czasie ilości podawanego paliwa. Środki ciężkości wyznaczono za pomocą zależności znanych z mechaniki ogólnej i przedstawiono na rys. 7. Zgodnie $z$ rys. 2, wśród analizowanych przypadków pomiarowych, można wyróżnić trzy formy wtrysku: jednoczęściową, zbliżoną do realizowanych przez konwencjonalne układy wtryskowe, jednoczęściową o modulowanych wartościach natężenia wypływu paliwa z rozpylacza oraz dwuczęściową. Oczywiście każdej formie wtrysku odpowiada inne położenie środka ciężkości, które jest jednak dla niej charakterystyczne. Jednoczęściową dawkę wtrysku cechują najwyżej położone środki ciężkości, co świadczy o zwartej formie przebiegu i relatywnie dużej dawce. Środki jednoczęściowych dawek z modulacją natężenia są przypisane mniejszym wartościom natężenia wypływu paliwa i przesunięte w kierunku większych wartości czasu. Oznacza to podawanie mniejszych dawek i większy udział drugiej części dawki w procesie wtrysku. Środek ciężkości dwuczęściowej dawki jest położony niżej w stosunku do dawki jednoczęściowej, a jednocześnie odpowiadają mu mniejsze wartości czasu. Jest to spowodowane krótszymi czasami wtrysku i mniejszym udziałem pierwszej części dawki w procesie wtrysku.

Jak wynika z powyższego opisu, za pomocą położenia środków ciężkości można w zwartej formie przedstawić intensywność procesu podawania paliwa do silnika i w

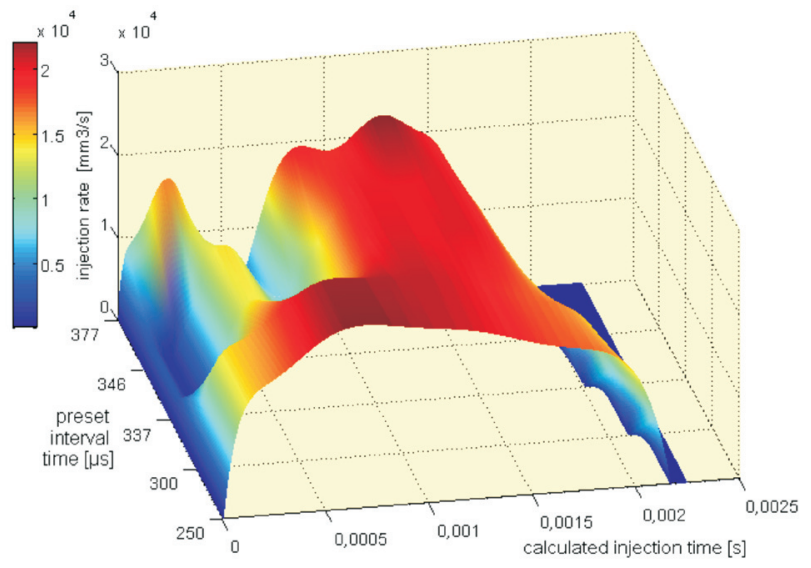

Fig 5. Injection rates a of two-part dose as a function of preset interval time

Rys. 5. Przebiegi wtrysku dwuczęściowej dawki paliwa w zależności od czasu przerwy i obliczonego czasu wtrysku 
of center of gravity, which is characteristic for each form of the injection. A single-part dose of the injection is characterized by the center of gravity at the highest location, which testifies to the compact form of the run and the relatively big dose. Centers of gravity of undivided doses with modulation of the flow rate are associated with smaller values of the fuel flow rate, shifted in the direction of higher values of time. This signifies the supply of smaller doses and the bigger share of the second part of the dose in the injection process. The center of gravity of a two-part dose is located lower (with respect to a single part dose), and simultaneously smaller values of time correspond to this center. This is caused by shorter injection times and the smaller share of the first part of the dose in the injection process.

As seen from the above description, using the locations of the centers of gravity, it is possible to present the intensity of fuel supply to the engine in a compact form and approximately describe changes in the process of heat release in the cylinder, as generated by changes of dosage.

As previously mentioned, in the case of the cases of measurement analyzed, comparisons of injection times were also performed, starting from the preset ones, and ending with calculated ones. The values of the times are presented in Fig. 8. The times of lift of the nozzle depicted here are the times read directly from runs of the voltage recorded in the chamber of the injection dose indicator, and reflecting increments of fuel pressure $[1,2]$. During the investigation of injection processes, they can be used for quick assessments of the direction of changes of analyzed values.

As can be seen, preset (blue line) and controlled times (black line) increase, which is connected with the use of longer interval times. Differences between these times do not exceed $1.9 \%$, which testifies to the correct operation of the controller. The values of the calculated times (green line) and the times of nozzle lift (red line) are at different levels. They are considerably bigger than the preset times and they decrease together with the growth of the interval time. In this figure the changes in the fuel dosage are also shown (yellow line), which decrease together with growth of the interval time.

In turn, in Fig. 9 percentage differences of preset and calculated injection times are compiled (green line), together with preset injection times and times of nozzle lift (red line). For the calculated times, these differences decrease together with the increase of interval time from $-112 \%$ to $-49 \%$. A similar character of the changes is present in the case of times of the lift, and the range of the differences, although smaller, takes similar values (from $-106 \%$ to $-45 \%$ ). Differences in the values analyzed result mainly from the methodol-

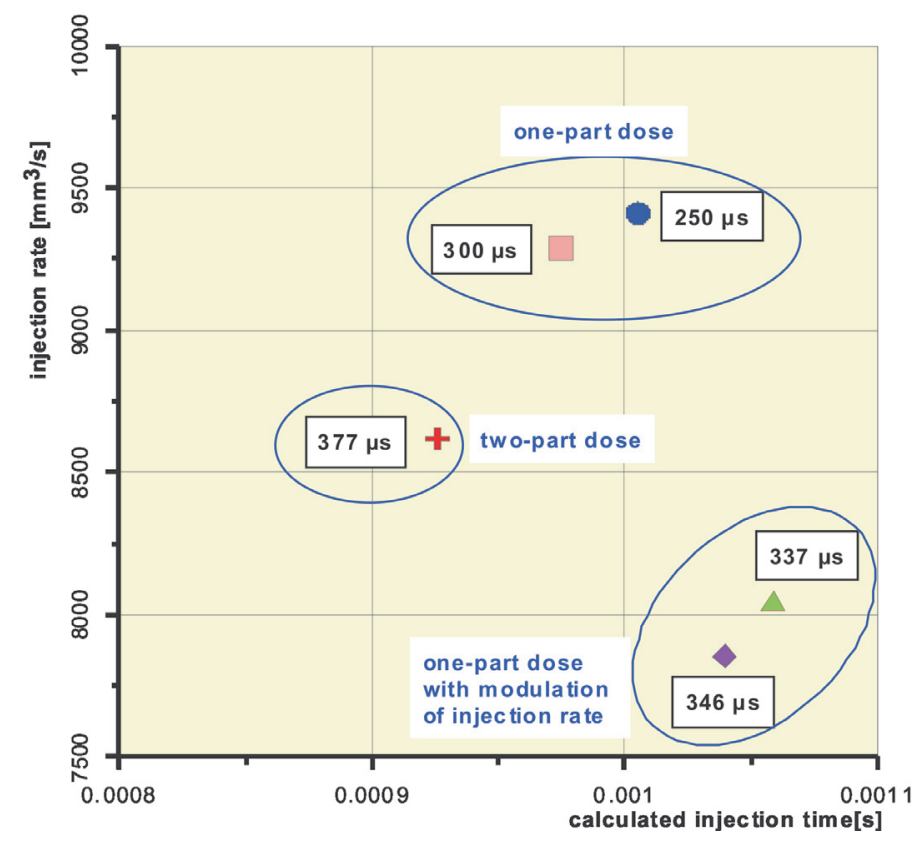

Fig. 7. Centers of gravity of the injection rates analyzed of a divided fuel dose Rys. 7. Położenie środków ciężkości analizowanych przebiegów wtrysku dzielonej dawki 


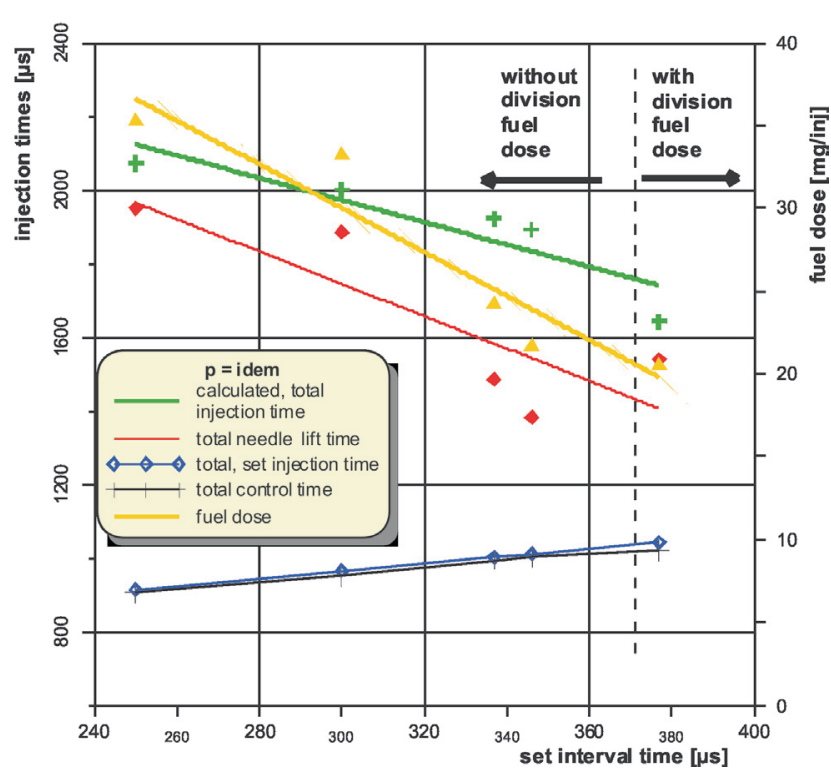

Fig. 8. Injection times of a two-part dose as a function of preset interval time

Rys. 8. Zmiany czasów wtrysku dwuczęściowej dawki w zależności od zadanego czasu przerwy

ogy of determination of injection runs, which is based on an approximation and the differentiation of averaged, measured pressure runs from the indicator's chamber. Special care is needed in the case of pressure runs obtained from single-part doses with modulation of the fuel flow rate from the nozzle. In such cases, the bigger differences are generated due to the character of the base curves.

\section{Summary and final remarks}

The results presented, for comparative analyses of injection runs, accomplished by injectors in a common rail system for different preset times of the interval have shown the considerable role of this value regarding the shape of the injection. With a multi-part injection, it determines the possibility of obtaining the following runs: undivided, undivided with modulation of the flow rate, or multi-part. Significantly, injection parameters, such as fuel's flow rate from the nozzle are also changed, and especially, the calculated injection times, which are always bigger than the total, preset ones. For a given value of pressure in the common rail, there exists a certain limit value of interval time interval time, for which division of the dose into parts is accomplished.

In particular, for the cases of the measurement analyzed, in the case of supply with a division (two-part) at constant fuel pressure, together with an increase in the interval time occur: a change in the form of the injection, up to a distinct separation of the preset division into parts, a decrease of the total, calculated injection time of about $20 \%$, a change in the percentage differences between the preset and calculated injection times, from an initial value reaching $100 \%$ to about $50 \%$ at division into parts, the supplied dose of the fuel decreases by about $40 \%$. Maximum values of injection intensity are reached after longer passages of time, calculated from the beginning of the process, whereas the change of the maximum values of the injection run reaches up to $20 \%$. The

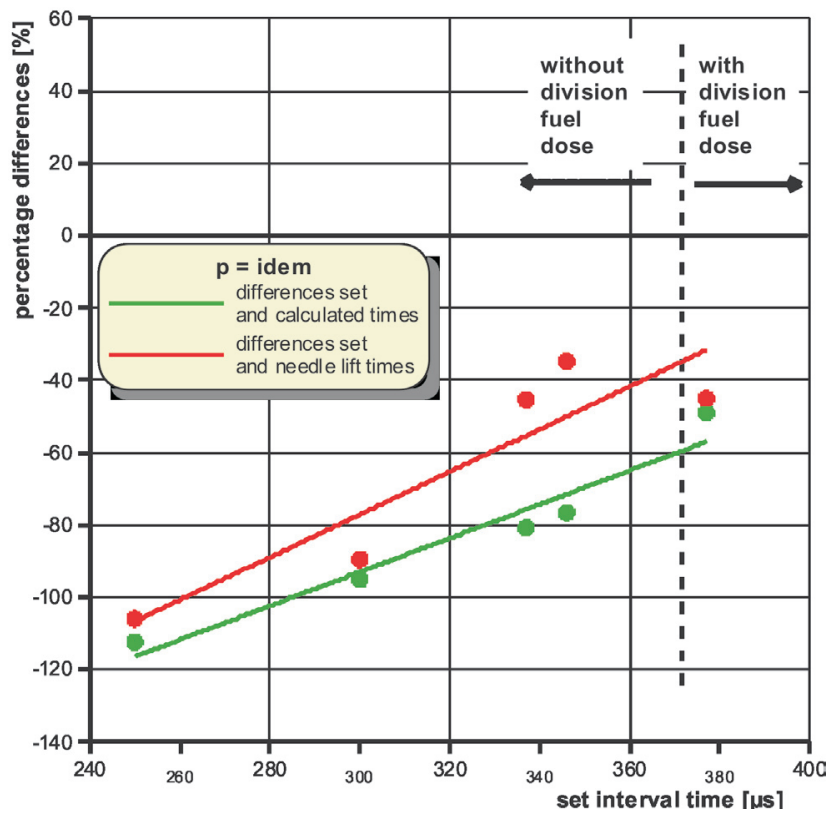

Fig. 9. Percentage differences of injection times of a two-part dose as a function of preset interval time

Rys. 9. Procentowe różnice czasów wtrysku dwuczęściowej dawki w zależności od zadanego czasu przerwy

Jak można zauważyć, zadane (linia niebieskiego koloru) i sterowane czasy (linia czarnego koloru) zwiększają się, co jest związane z zadawaniem coraz większych czasów przerwy. Różnice między nimi nie przekraczają $1,9 \%$, co świadczy o właściwej pracy sterownika. Inny poziom przyjmują wartości obliczonych czasów (zielona linia) oraz czasów uniesienia iglicy (czerwona linia). Są znacznie większe od zadanych i zmniejszają się wraz ze wzrostem czasów przerwy. Na rysunku również przedstawiono zmiany dawkowania paliwa (linia żółtego koloru), które to wartości zmniejszają się wraz ze wzrostem czasu przerwy.

Z kolei na rys. 9 zestawiono procentowe różnice zadanych i obliczonych czasów wtrysku (linia zielonego koloru) oraz zadanych czasów wtrysku i czasów uniesienia iglicy (linia czerwonego koloru). Dla obliczonych czasów różnice zmniejszają się ze wzrostem czasu przerwy od $-112 \%$ do -49\%. Podobny charakter zmian występuje dla czasów uniesienia, a zakres różnic choć mniejszy, przyjmuje zbliżone wartości (od -106 \% do -45\%). Różne wartości analizowanych wielkości wynikają przede wszystkim z metodyki wyznaczania przebiegów wtrysku, która opiera się o procesy aproksymacji i różniczkowania uśrednionych, zmierzonych przebiegów ciśnienia z komory indykatora. Szczególnej uwagi wymagają przebiegi ciśnienia otrzymane w wyniku wtrysku jednoczęściowych dawek z modulacją natężenia wypływu paliwa z rozpylacza. W tych przypadkach, z uwagi na charakter krzywych bazowych są generowane największe różnice.

\section{Podsumowanie i uwagi końcowe}

Przedstawione wyniki porównawczych analiz przebiegów wtrysku, realizowanych przez wtryskiwacze układu 
latter initially decline, but after occurrence of the division they increase. In the complete range of values analyzed a reduction of the speed to reach the maximum value of the fuel flow rate from the nozzle occurs.

Knowledge of calculated injection times is one of the elements enabling development of control algorithms for Diesel engines. It enables substantial shortening of work on software applications in the controller of the power unit. Results of comparative analyses of preset and calculated injection times can aid in computation of the energy stream supplied to the combustion chamber during individual phases of the process, especially when surface interpolation (3D) is used, describing the run of the injection. The results can also be helpful in the determination of characteristic points of the injection, such as the maximum injection pressure or the fuel flow rate from the nozzle.

This paper has been written in the implementation of research project No. 5178/B/T02/ᄀ2011/40 financed by the National Science Centre.

\section{Bibliography/Literatura}

[1] Knefel T.: The evaluation of the characteristic injection times of a multiple fuel dose. Journal of KONES: Powertrain and Transport 2011, vol. 18 no. 2 , pp. 205-213.

[2] Knefel T.: Comparative analysis of a selected times of injection of multi-part dose of fuel, Czasopismo Techniczne 2012, z. 9. ISSN 0011-4561, pp. 115-129.

[3] Knefel T.: Electronically controlled indicator of injection, Combustion Engines, No 2007-SC2, pp.74-79, 2007.

[4] Pietras D., Gilowski T., Knefel T.: A program to analyze the combustion process in diesel engine, Combustion Engines, $\mathrm{nr}$ 3(146), pp. 1-5, 2011.

[5] Stelmasiak Z., Knefel T., Larisch J.: A development control unit for Common Rail injection system - KSSiP-1, Combustion Engines, 2005.

[6] Stelmasiak Z., Knefel T., Larisch J.: The influence of the time break of the fuel divided dose on the work parameters of the injector Common Rail system, Combustion Engines, No 2007 SC2, pp. 173-180.

[7] Wang X., Kikutami T., Takeuchi K., Nakane N.: Development Toward Diesel Revolution Using Ultra High Pressure CRS with Closed-Loop Control System for Heavy Duty Engine, Proceedings of the World Automotive Congress FISITA 2010, F2010-A-164, Budapest 2010. common rail dla różnych zadanych czasów przerwy, wykazały istotną dla formy wtrysku rolę tej wielkości. Przy wieloczęściowym wtrysku, decyduje ona o możliwości uzyskania przebiegu: jednoczęściowego, jednoczęściowego z modulacją natężenia wypływu bądź wieloczęściowego. W istotny sposób zmieniają się również parametry wtrysku, takie jak natężenie wypływu paliwa z rozpylacza, a zwłaszcza obliczone czasy wtrysku, które są zawsze większe od całkowitych, zadanych. Dla danej wartości ciśnienia w zasobniku istnieje pewna wartość graniczna czasu przerwy, dla której jest realizowany podział dawki na części.

W szczególności, dla rozpatrywanych przypadków pomiarowych, przy zadawaniu dwuczęściowego podziału, przy stałym ciśnieniu paliwa, wraz ze wzrostem czasu przerwy następuje: zmiana formy wtrysku, aż do wyraźnego wyodrębnienia zadanego podziału na części, zmniejszanie całkowitego, obliczonego czasu wtrysku o około $20 \%$, zmiana procentowych różnic między zadanymi a obliczonymi czasami wtrysku, od początkowych wartości sięgających $100 \%$ do około $50 \%$ przy podziale na części, zmniejsza się podawana dawka paliwa około $40 \%$. Maksymalne wartości natężenia wtrysku są osiągane po upływie coraz dłuższych czasów liczonych od początku procesu, a zmiany maksymalnych wartości przebiegu wtrysku dochodzą do $20 \%$. Te ostatnie początkowo maleją, a po wystąpieniu podziału rosną. W całym rozpatrywanym zakresie następuje zmniejszanie prędkości osiągania maksymalnej wartości natężenia wypływu paliwa z rozpylacza.

Znajomość obliczonych czasów wtrysku jest jednym z elementów umożliwiających projektowanie algorytmów sterowania silników o zapłonie samoczynnym. Pozwala znacząco skrócić prace przy aplikacji oprogramowania $\mathrm{w}$ sterowniku jednostki napędowej. Wyniki przeprowadzonej porównawczej analizy zadanych i obliczonych czasów wtrysku, mogą służyć obliczeniu strumienia energii dostarczanej do komory spalania w poszczególnych fazach procesu, zwłaszcza po zastosowaniu interpolacji powierzchni (3D) opisujących przebieg wtrysku. Mogą być również pomocne przy wyznaczaniu charakterystycznych parametrów wtrysku, takich jak: maksymalne ciśnienie wtrysku czy natężenie wypływu paliwa $\mathrm{z}$ rozpylacza.

Publikacja powstała $w$ ramach realizacji projektu badawczego nr 5178/B/T02/2011/40 finansowanego ze środków Narodowego Centrum Nauki.
Tomasz Knefel, DEng. - assistant professor in the Faculty of Mechanical Engineering and Computer Science at University of Bielsko-Biała.

Dr inż. Tomasz Knefel - adiunkt na Wydziale Budowy Maszyn i Informatyki Akademii TechnicznoHumanistycznej w Bielsku-Białej. e-mail:knefel@ath.bielsko.pl

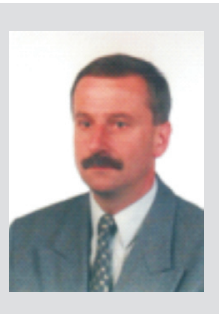

Dariusz Pietras, DEng. - assistant professor in the Faculty of Mechanical Engineering and Computer Science at University of Bielsko-Biała.

Dr inż. Dariusz Pietras - adiunkt na Wydziale Budowy Maszyn i Informatyki Akademii Techniczno-Humanistycznej w Bielsku-Białej.

e-mail:pietras@ath.bielsko.pl

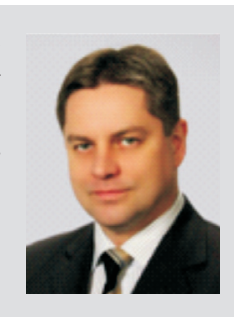

